Running head: CRITICAL RACE HUMOR

\title{
Critical Race Humor in a Postracial Moment: Richard Pryor's Contemporary Parrhesia
}

Author:

Jonathan P. Rossing

Published in Howard Journal of Communications

This is the author's manuscript of the article published in final edited form as:

Rossing, Jonathan P. (2014). Critical Race Humor in a Postracial Moment: Richard Pryor's Contemporary Parrhesia. Howard Journal of Communications, 25(1), 16-33. DOI: $10.1080 / 10646175.2013 .857369$ 


\begin{abstract}
Racial truth-telling becomes a difficult project given the current socio-political context that privileges postracialism and neoliberal individualism. Critical race humor, however, remains one public and popular discourse where people not only speak but also engage powerful racial truths. This essay presents critical race humor as a contemporary form of parrhesia, or frank and courageous criticism. As a critical practice, parrhesia resonates with tenets of critical race scholarship and critical communication scholarship. Using the truth-telling comedy of the lateRichard Pryor as a case study, this essay suggests that critical race humor could be understood as parrhesia for our time. Moreover, critical race humor as a form of public pedagogy might provide people with the skills and habits of thought necessary to think critically about and transform racial knowledge and reality.
\end{abstract}

Keywords: parrhesia, critical race theory, rhetoric, humor, Richard Pryor 


\section{Critical Race Humor in a Postracial Moment: Richard Pryor's Contemporary Parrhesia}

The truth is gonna be funny, but it is gonna scare the shit outta folks (Pryor \& Gold, 1995, p. 110).

Telling racial truths invites resistance and opposition. People wrestle over whether to bury this country's racial past or to remember it in vivid detail. National narratives fail to confront honestly the unrealized promises of freedom and justice. Postracial attitudes reject racial truths and obscure the persistence of racial hierarchies and privilege in favor of the belief that race no longer matters (Bonilla-Silva, 2006; Squires et al., 2010). Neoliberal ideology similarly thwarts racial truth telling by depoliticizing social difference and inequality. From a neoliberal orientation, social and institutional injustices become merely the individual failures of people who compete unsuccessfully in the marketplace (Enck-Wanzer, 2011; Jones \& Mukherjee, 2010). Together, postracialism and neoliberalism relegate racial injustice to a past disconnected from present realities and perpetuate an antiracial perspective that views any invocation of race as akin to racism. Further complicating this socio-political context is a reduced knowledge of history and public affairs and a waning sense of civic engagement and responsibility that cause people to ignore the most pressing social problems (Giroux, 2001). Thus, Michael Lacy and Kent Ono (2011) asserted, "Race and racism are often difficult to isolate, interpret, and explain. Race and racism are deflected, denied, disavowed, minimized, and excused" (p. 2).

In this essay, I argue that critical race humor offers an antidote to these challenges of racial truth-telling, particularly at a time when postracialism and neoliberalism rule. Racial truth- 
telling and criticism artistically angled through humor has the potential to defy dominant practices and ideologies that promote the erasure of material realities of race. By critical race humor, I mean to identify humorous discourses that participate in the exploration and transformation of the power relationships, institutional practices, cultural beliefs, and ideologies that shape material realities of race and racism. Drawing on central tenets of critical race theory and their intersections with critical communication scholarship (Delgado \& Stefancic, 2012; Rossing, 2010), I understand critical race humor to direct attention to the construction of race and the material consequences of those constructions. It brings to the surface the unexamined ordinariness of racism and racial matters in everyday life in ways that open spaces and create possibilities for challenging racial knowledge and practices. Although this essay focuses on stand-up comedy, my conception of critical race humor includes a broad range of discursive sites and genres - from sketch comedy to YouTube videos, from satire to parody and much more.

Humor has long been associated with the practice of criticism. Joseph Boskin (1997) argued that one role of the comic is to expose unexamined issues and confront taboos as a social and political critic. Artists turn to humor to speak truth to power, to address pressing and vexing socio-political affairs, and target the vices and moral failings of society, political institutions, and individuals (Day, 2011; Gelvin, 2000; Jenkins, 1994; Jones, 2009; Kercher, 2006; Lerner, 2009; Test, 1991). In relation race, marginal voices in U. S. culture have used humor to expose injustice and oppression. In the context of enslavement, for example, African Americans developed practices of misdirection, folk humor, double-voiced narratives, satire, and more in order to voice truths that could easily result in punishment or death (Foxx \& Miller, 1977; Gates, 1988; Watkins, 1994; Zolten, 1993). Critic Saunders Redding noted of black humor: "It is real. ... It is very often true - and the truth strikes deep into the follies, the paradoxes, the ambiguities, 
and the pulpy moral fiber of American life" (Watkins, 1994, p. 40). Redding's observation characterizes not only Black artists such as Dick Gregory, Chris Rock, or Wanda Sykes, but also artists from a wider range of racial identities; Margaret Cho (Korean American), Russell Peters (Indian-Canadian), and Stephen Colbert (Irish American), for example, powerfully critique and expose racial realities through humor (e.g. Pelle, 2009; Rossing, 2012).

In order to advance my argument for critical race humor as a truth-telling practice, I employ as a heuristic the Greek ideal of parrhesia. Etymologically "to say everything," parrhesia named a practice of frank criticism that rejected hierarchy. In light of contemporary injustices and oppression, Cornel West (2004) argued for a commitment to the practice of parrhesia, which "unsettles, unnerves, and unhouses people from their uncritical sleepwalking" (p. 16). As a method for truth-telling and problematization parrhesia presents opportunities to engage and transform the ideological, representational, and material circumstances that shape everyday life. I argue that critical race humor represents a contemporary manifestation of parrhesia and, as such, it participates vitally in the politics of public pedagogy.

The truth-telling humor of the late Richard Pryor illustrates these possibilities for humor. His artistic, poignant criticism of racial culture proves valuable for considering critical race humor as parrhesia. Through an analysis of Pryor's stand-up comedy performances I will argue that parrhesia carries valuable purchase for scholars attempting to expose racial truths and activate spaces to talk about race, especially against the challenges of postracialism and neoliberalism. Recognizing Pryor's contributions also promises to enrich the ongoing scholarly conversation on socio-political humor. To borrow Celeste Condit's (1990) admonition of rhetorical critics, the most frequently celebrated models of humor are "texts with which a certain class of white male [and female] scholars find themselves consubstantial," thereby producing "a 
grossly truncated vision" of excellence (p. 337). Recent scholarship, my own included, too often constructs a canon that features mostly white, male comedians and late night hosts (e.g., [author], Day, 2011; Jones, 2009; Waisanen, 2009).

The essay proceeds in three parts. First, I outline characteristics of parrhesia and articulate this ideal with contemporary critical rhetorical race scholarship and humor. Second, I turn to Pryor's comedy as an exemplar of contemporary parrhesia. This section begins with a brief background on Richard Pryor and the context of his performances. Then, I outline two characteristics of Pryor's critical race humor that mark it as parrhesia for our time. Specifically, 1) Pryor's humor created pathways for marginal perspectives to problematize dominant, shared truths, and 2) Pryor used humor to manage the vulnerability and risk of racial truth-telling through the creation of a parrhesiastic contract. In conclusion, I consider the ways in which critical race humor such as Pryor's participates in public pedagogies on race.

\section{Parrhesia, rhetoric, and racial truths}

Parrhesia originated as a moral quality for speaking in Athenian democracy, a result of the emerging importance of public address, freedom of thought, and communal discussion (Ober, 1989). Michel Foucault's $(2001,2005)$ lectures on parrhesia traced the evolution of this practice of critique both in politics and philosophy in order to craft a genealogy of the critical attitude and understand processes of problematization. Foucault identified parrhesia as frank criticism, speaking with an openness that allows one to utter what must be said despite the risk that the spoken truths might anger or hurt the receiver. The ideal of parrhesia compelled citizens "to confront, oppose, or find fault with another individual or a popular view in a spirit of concern for illuminating what is right and best" (Monoson, 2000, p. 53). Parrhesia, therefore, implies a responsibility for criticism. The truth-teller is "free to keep silent. No one forces him to speak, 
but he feels that it is his duty to do so" (Foucault, 2001, p. 19). While the pejorative sense of parrhesia refers to a foolishly unfettered tongue, it most frequently characterizes sincere truthtelling in which a speaker counters dominant beliefs with experiential truths or offers guidance toward another individual. Political parrhesia originates from one in an inferior position against a more powerful person or institution: a citizen challenging a political system, criticizing the majority, pointing out shortcomings in a democracy, or accusing the state of injustice, for example. Personal parrhesia characterizes the practice of spiritual guidance in which the truthteller seeks a personal transformation that alters not only beliefs and opinions, but also “one's style of life, one's relation to others, and one's relation to oneself' (Foucault, 2001, pp. 12, 106). Personal parrhesia seeks to educate people so that they will develop an autonomous relationship in which they freely choose to act in accordance with newly understood truths (Foucault, 2005).

The rhetoricity of parrhesia warrants a brief comment. Foucault $(2001,2005)$ stressed an opposition between parrhesia and rhetoric predicated on well-worn fears of rhetoric as manipulation, pandering, and sophistry. While parrhesia concerned true discourse, rhetoric only concerned persuasion and, therefore, encompassed the potential for lying and deceit. Valorizing authenticity and transparency, parrhesia fostered suspicion of those who spoke with obvious artistry (Markovits, 2008; Saxonhouse, 2006). Such impoverished understandings of rhetoric limit the possibilities for imagining parrhesia as a contemporary rhetorical practice. Parrhesia, however, resonates with contemporary understandings of rhetoric (Walzer, 2013). In particular, parrhesia operates as epistemic: the frank truths represent a discursively constructed reality based on a speaker's personal relationship to truth rather than transcendent, sacrosanct standards (Foucault, 2001; Monoson, 2000). The parrhesiastes is not a conduit for divine truth or fundamental precepts. Experiential, personal truths inform the criticism. This perspective on 
truth reflects the Athenian understanding that political and social truths are brought into being through socially constituted meaning and common norms rather than permanent, natural facts (Ober, 1994). In short, parrhesia represents truth-telling that constitutes knowledge, opinion, and identity.

This constitutive quality of parrhesia aligns with a central tenet of critical race and communication scholarship: the social construction of race. Critical race scholarship stresses that racial meaning, attitudes and knowledge are not natural, fixed realities, but rather products of social relationships and dominant, popular, and vernacular discourses such as law, education, and popular culture (Delgado \& Stefancic, 2012; Hasian \& Delgado, 1998; Lacy \& Ono, 2011; López, 2006). Thus, critical race scholarship accents the importance of voice, narrative, and the power of naming one's reality (Delgado, 1989; Dickinson, 2012). Voicing invisible or previously inaccessible truths, or "looking to the bottom," critical race scholarship brings into focus "the perspective of those who have seen and felt the falsity of the liberal promise" (Matsuda, 1987, p. 324). Such first-person accounts of racism challenge claims of neutrality and objectivity, broaden the points of view circulating in public discourse, and constitute new social knowledge that reflects experiences and perspectives informed by racial oppression. These counter-stories create conditions that might "catalyze the necessary cognitive conflict to jar dysconscious racism" (Ladson-Billings \& Tate, 1995, p. 58). Critical rhetorical race scholarship, then, resonates with the ideal of parrhesia as frank criticism, particularly through the critique of dominant political institutions and the problematization of ideologies such as liberalism, legal neutrality, political rationality, and more.

Bold criticism about race, however, requires courage and rhetorical sophistication in order to confront and overcome resistance to racial truths. First, truth-tellers must overcome the 
fact that "racism makes the words and ideas of blacks and other despised minorities less saleable, regardless of their intrinsic value, in the marketplace of ideas" (Lawrence, 1990, p. 468). Second, postracialism and neoliberalism espouse the diminished salience of race and consequently people ignore systemic oppression and dismiss the experiential truths that attest to the significance of race. Within this socio-political context "racial" topics are readily recast and attacked as "racist." Consequently, speaking truths about race often places a speaker at risk of anger, disfavor, exclusion, or even death—both figurative and literal—such as the "spirit murder" that occurs when the stories of those who experience racial oppression are discounted and people are blamed for their own oppression (Williams, 1987). Given this opposition, racial truths such as those offered by critical race scholarship require rhetorical sensibilities that create avenues for these truths to be heard and received (Olmsted, 1998). The speaker must choose the right moment to utter the criticism and account for situational variables such as the state of mind of those receiving the criticism. Attending to this rhetorical imperative, Foucault (2005) argued, "It is precisely according to the person to whom one speaks and the moment one speaks to him that parrhesia must inflect, not the content of the true discourse, but the form in which this discourse is delivered" (p. 384). Said otherwise, when articulated with figured discourse criticism becomes "more effective because more impressive and artful" (Jarratt, 2010, p. 287).

The necessity for criticism that is at once dutiful, purposeful, strategic, and timely invites a return to critical race humor. As a rhetorical practice, humor enables and advances parrhesia's critical end. In the following section, I turn to Richard Pryor's critical race humor as an exemplar of parrhesia.

\section{Richard Pryor \& contemporary parrhesia}


Richard Pryor's truth-telling humor epitomizes parrhesia for our time and illustrates the possibilities of critical race humor as a truth-telling, pedagogical practice. Pryor occupies a unique place in the American comic tradition. Pryor was not the first prominent Black comedian to address White audiences with perspectives on race; performers such as Dick Gregory and Godfrey Cambridge prepared the way for Pryor. However, he gained the most notoriety and fame compared to other African American comedians performing during the 1960s and 1970s. He received one Emmy award and five Grammy awards and was named the inaugural recipient of the Kennedy Center Mark Twain Prize for American Humor in 1998. Pryor receives credit for inspiring humorists who followed him such as Whoopi Goldberg, Chris Rock, and Dave Chappelle. Although other artists might equally exemplify parrhesia, none lay claim to the legacy or cultural impact of Pryor.

Pryor offered an affecting, penetrating perspective on everyday life from his vantage point as an African American male in a society struggling with racism. He distinguished himself from other artists by presenting previously ignored and unmoderated perspectives of black culture. Pryor explained in his autobiography, "There was a world of junkies and winos, pool hustlers and prostitutes, women and family screaming inside my head, trying to be heard" (Pryor \& Gold, 1993, p. 93). His recurring characters candidly revealed painful personal experiences and truths from the margins. Critics celebrated Pryor's provocative performances for their intense "faithfulness to the truth," "brutal honesty," and "brutal sociopolitical truths" (Stanford, 2005, p. 10; Waldron, 2006, p. 6; Watkins, 1994, pp. 552, 558). He was, in short, a "master of telling the truth" (Feeney, 2005, B21).

Pryor's truths required courage and artistry as he confronted his audience, white audience members in particular, with harsh realities of race and racism. Zolten (1993) wrote of African 
American comedy, "[T] he act of standing before the oppressor and telling the truth about oppression, even though presented in the guise of entertainment, was an act of bravery" (p. 72). Pryor rose to stardom in the 1970s following the height of the civil rights movement and almost two decades marked by protests, riots, and assassinations and by significant socio-political transformation such as desegregation and the passage of legal protections against discrimination. In the 1970s, overt racial discrimination began to decline while racial attitudes found more indirect and covert expression in response to busing, newly elected African American leaders, reports of racial discrimination in the military, and more. The decade witnessed the rise of both neoliberalism and postracialism, orientations epitomized by work such as William Julius Wilson's The Declining Significance of Race (1978).

Pryor's capacity for speaking truths about race in such a context proves valuable for exploring critical race humor as parrhesia. His critiques of racism expressed a sense of urgency and duty to speak truth when the security of silence is no longer viable. He unabashedly exposed truth without deference to socio-political status, popularity, or hierarchy and "without concern about whom the truth may offend" (Saxonhouse, 2006, pp. 88-89, 94). His carefully crafted "comic persona" enabled him to introduce "multiple lived experiences and multiple articulations of blackness" into the public discourse on race (Haggins, 2007, pp. 5-6, 60). Moreover, Pryor sought to create a more just community in relation to race: a motivation "to show us our foibles and to put us on the right path" appeared to drive his critiques (Haggins, 2007 p. 60). Thus, in spite of audience discomfort with direct confrontations of racism and shifting attitudes toward the salience of race, Pryor "transcend[ed] racial boundaries and capture[d] a huge audience of admirers in virtually every ethnic, economic and cultural group in America" (Watkins, 2005, p. A24). 
To be certain, Pryor's critical orientation had blindspots. His humor paradoxically struggles against cultural and institutional practices of racism while sexism and homophobia marred his routines. By recognizing Pryor's contributions to a resistant public pedagogy on race and racism, I do not intend to elide either the complex intersections of race, gender, and sexuality or the ways in which Pryor reproduced other systemic oppressions. Rather than dismissing Pryor's work for its impurities, I believe it is possible to mine his performances for insights that benefit contemporary critical race scholarship while acknowledging his investments and assumptions within intersecting systems of oppression. Dustin Goltz (2013) argued for resistance of the "critical-norm," a routinized critique that identifies rigid polarities of good/bad, right/wrong, sexist/not-sexist, and so on, which obscure the complexities of critical projects. Moreover, following Goltz (2013), I assert that Pryor's contradictory interests provide an opportunity to reflect on a paradox that every critical scholar confronts; despite our best intentions and careful reflection, we often find ourselves complicit in sustaining and reproducing oppressive power relations and structures. As an able-bodied, gay, white, male scholar committed to the project of critical race scholarship, I am sensitive to both the complexities of intersectionality and the need to reflect on my own limitations, privileges, and participation in oppressive systems. The courage associated with the act of criticism demands the grace to confront the truth of our ignorance and to identify our complicity in systems of domination.

The following examples from Pryor's stand-up performances illustrate parrhesia as both political and personal criticism of racial oppression. First, Pryor's critical race humor features creative counter-storytelling that reconstructs and recalibrates dominant narratives. Second, Pryor's humor constructs a unique parrhesiastic contract that strategically mitigates the 
vulnerability and risk that accompany racial truth-telling. Thus, Pryor opens possibilities for resistant audiences to hear and digest truths that they might otherwise reject.

\section{Problematizing dominant truths from the margins}

Major revisions to dominant knowledge require insights from those outside of dominant political culture whose experiential truths disrupt the status quo and challenge dominant knowledge and conventions. Critical race humor provides a pathway to parrhesia for speakers who are underpowered in relation to their audience. Such humor empowers marginalized critics to problematize shared and sacred truths, and it provides opportunities to undermine oppressive forces that stifle justice. Bursting with counterhistories and narratives that offer new perspectives on commonly held knowledge, Pryor's work epitomizes the potential of critical race humor as a strategy for challenging dominant ideologies.

One of Pryor's most powerful critiques of dominant knowledge appeared in his Grammy Award-winning album Bicentennial Nigger (1976). While the nation celebrated two hundred years of independence, Pryor's act of political parrhesia recalibrated and reframed the dominant, patriotic narrative. As an occasion for constructing public memory, the bicentennial celebration featured a case of "selective amnesia" in which public discourse omits the events and stories that complicate narratives of progress and unity (Hoerl, 2012). Against this amnesia, Pryor enacted a type of "historical recovery" insofar as he aimed to "reimagine democracy by including forgotten or silenced voices in our national dialogue" (Hartnett, 2010, p. 77). Pryor introduced the United States' Bicentennial with a creative problematization of the national commemoration: "We are celebrating two hundred years — of white folks kickin' ass." His joke clearly announced the coming counter-narrative and foregrounded a doubled perspective reminiscent of Frederick Douglass' 1852 address, "What to the slave is the fourth of July?" particularly insofar as Pryor 
employs irony to juxtapose and contrast multiple perspectives on the occasion (Lucaites, 1997; Terrill, 2003). Like Douglass, Pryor invited his audience to hold in focus both the institutionalized, patriotic fervor and the forgotten voice of a slave. A triple ratamacue drum cadence created a colonial, patriotic air as Pryor introduced his title character: "Gonna have a Bicentennial Nigger ... two hundred-years-old, in blackface with stars and stripes on his forehead ... and he'll have that lovely white folks expression on his face." His character's name alone introduces the clash of perspectives that characterized this performance. On one hand, the mention of the bicentennial invokes a proud moment of national celebration; on the other, a racial epithet laden with a history of oppression casts a pall over the festivities. The character embodies this juxtaposition of competing narratives, adorned both with nationalistic symbols and the mark of minstrelsy. Pryor assumed the role of the Bicentennial Nigger with ingratiating laughter and foolish joviality characteristic of a stereotypical minstrel. This mask, however, allowed Pryor's character to enact an ironic celebration of the nation that became increasingly morose with each line.

The drum cadence gave way to the "Battle Hymn of the Republic," underscoring the mission of his comic persona-His truth goes marching on. Supplementing the bicentennial celebration, Pryor's character regaled the audience with the nation's history of racial oppression. 'I'm just so thrilled to be here—over here in America. I'm so glad y'all took me out of Dahomey." At once, his mocking praise fulfilled expectations for a celebratory attitude and reminded the audience of a history of violent abduction and displacement. Next, his persona exposed the physical and psychological tolls of racial oppression while maintaining his caustic praise. "I used to could live to be a hundred fifty. Now I die of high blood pressure by the time I'm fifty-two. That thrills me to death. I'm just so pleased America is goin' to last." Pryor's 
character recounted the horrors of the slave trade and the Middle Passage, recollecting a massive death toll where three hundred sixty out of four hundred died on the journey across the Atlantic. Then, he shifted attention to the lives of those who survived the slave ships: "They split us all up. Yessiree, took my mama over that way, took my wife that way, took my kids over yonder. I'm just so happy. ... I don't know what to do if I don't get two hundred more years of this. Lawd have mercy. Yessiree." The "Battle Hymn" swelled to a triumphant fanfare as Pryor's character concluded, "I don' know where my own mama is now. She up yonder in that big white folks in the sky. Y'all probably done forgot about her." The music stopped and Pryor broke character abruptly: "But I ain't gonna never forget it."

Pryor's counter-narrative invited the audience to remember the injustice and cruelty, the blood and bodies that enabled the prosperity of the country. Pryor contrasted a shortened lifespan, implicitly due to the stress of racism, with reverence for America's dominant, enduring legacy. The biting irony of being "thrilled to death" by these experiences punctuated the hypocrisy of a celebration made possible, in part, by a history of oppression. His satiric wish for two hundred years of continued dehumanization situated racial oppression as an enduring reality. He offered these realities against the selective amnesia of the bicentennial celebration, thereby denying audiences the comfort of forgetting the oppression and sacrifices of parents, children, and spouses. Praise for the dominant narratives of American exceptionalism sits uncomfortably against these inconvenient truths. Pryor's conclusion struck the final discordant tone against the false harmony of selective amnesia that marked the bicentennial celebration. He cast off the façade of minstrelsy and delivered his admonishing punch line with simmering rage. Pryor's shift in tone amplified his effort to undermine patriotic nostalgia and re-direct the national memory. 
His monologue does not simply ask the audience to empathize with the torment of his character or the destroyed lives he recounts; instead, Pryor invited judgment. His switch from forgetting "her" to forgetting "it" signals the scope of his political parrhesia. He introduced a suppressed, marginalized perspective in order unveil a history of unrelenting, systemic oppression. Furthermore, Pryor's characterization of the bicentennial persona attacked the workings of power and privilege that marginalize minority dissenters, constrain criticism, and egregiously erase counter-narratives from public consciousness. His performance indicted the imposition of dominant socio-political visions and directed attention to the ongoing struggle over cultural memory where what we remember is integrally tied to who gets to remember (Browne, 1999).

Elevating a marginal voice through humor allowed Pryor to expose the distance between what the nation professes to be and what it is. Hall (1996) argued that people engaged in particular cultural struggles over representation, identification, and justice must "use the resources of history, language and culture in the process of becoming rather than being” (p. 3). Indeed, Pryor integrated histories of slavery and minstrelsy with the language of patriotism in order to challenge the dominant construction of knowledge and combat the erasure of the past. However, these stories must be received and digested if they are to move a community or society forward toward a better world. The next section suggests that humor creates conditions for such reception, particularly in relation to racial truths.

\section{Humor \& the parrhesiastic contract}

Parrhesia must adapt to audience and context and operate within recognizable conventions so that the frank truths appear plausible and compelling. A truth-teller cannot merely assert an unwavering critical perspective and assume that any reasonable person would accept 
the claim. Moreover, the truth teller must account for the state of mind of the interlocutor so as to correct without severe admonishment or acrimony, which prevent the reception of criticism (Foucault, 2005). As discussed above, racial truth-telling in particular must work through barriers that render racial realities incomprehensible and unpalatable. White people, for example, frequently feel attacked and disparaged in conversations about racial oppression (Kendall, 2006). Pryor's earliest recorded performance, Live and Smokin' (1971), highlighted these racial ideologies and attitudes that erect barriers to truth-telling practices. "Black people have a lot to overcome and it ain't just the mountain," Pryor explained. "Martin Luther King, said, 'I have been to the mountaintop.' I've been to the mountaintop, too, and I looked over the top, and what did I see? More white folks. With guns." His reference to King's final speech, only three years removed from King's assassination, established an important context for his punchline. $\mathrm{He}$ animated a cultural hero who strove tirelessly for social justice, then undermined the postracial narrative that equality had been achieved. His quip about armed white people defending the mountaintop introduced a humorous, yet sobering, incongruity to the metaphor for social mobility and racial equality. These gun-wielding protectors of the status quo exposed not only the vehement, violent opposition to racial justice, but also the antagonism that rendered him vulnerable for this confrontational truth. After the punchline, Pryor altered his voice to the constrained, nasal pitch he used to characterize white people: “This ain't as funny as we thought it was gonna be." His mimicry of the white audience members' discomfort with racial reality revealed the more benign but equally resistant attitude to racial equality that marginalizes nondominant perspectives and complicates truth-telling practices.

Given the cultural context, Pryor required both courage and rhetorical sensibility in order to overcome opposition to his experiential truths. Pryor adeptly used humor to establish a 
"parrhesiastic contract" with the audience, thereby mitigating the risk associated with his truths. Foucault (2001) described this contract as one in which the party with power and in need of truth granted the parrhesiastes the privilege of presenting truths without the threat of punishment. This tacit cultural contract is moral, not legal or institutional, and thus truth-telling still carries some potential for consequence. However, the agreement constructs a sanctioned space for truthtelling that lessens the risk and vulnerability of criticism. Critical race humor offers an avenue by which truth-tellers might render criticism more palatable and help others receive and digest racial truths. By making people laugh as they confront the truth, the humorist constructs a parrhesiastic contract that shields her from sharp retaliation. Humor also protects the receivers of criticism from acrid attacks that would preclude the possibility of reception and transformation.

As a contemporary parrhesiastes, Richard Pryor strategically overcame opposition to racial truths through humor without diminishing the critical project. Indeed, Watkins (1994) argued that Pryor's "astonishing array of dramatic and comic skills" enabled him to "speak candidly and successfully to integrated audiences the way black people joked among themselves when most critical of America" (p. 562). Pryor's discussion of racial profiling and police brutality from his album That Nigger's Crazy (1974) typifies the construction of a parrhesiastic contract through humor. Pryor tread strategically into the realm of oppressive encounters with law enforcement. "Cops put a hurtin' on your ass, man. You know, they really degrade you." Pryor conveyed an experiential truth about racial experience through a broader frame, more inclusive of his audience. Although he could have argued, "Police degrade black Americans," or more specifically "black men," he included everyone in the degrading experience of racial profiling with the generalized "you." The broad interpellation invited the entire audience into his narrative and created a shared exigency before Pryor increased the stakes of his criticism. 
However, it also protected both Pryor and his audience. Specifically, by starting from common ground Pryor assured that the audience might not immediately dismiss his experiential truth. Additionally, Pryor safeguarded his audience from feeling vilified. He initially avoided a whiteblack framing that some in his audience might have perceived as confrontational or divisive and that may have foreclosed the possibility of mutual identification and understanding.

Next, Pryor directly exposed oppositional constructs that might prevent his critique from gaining a hearing: "White folks don't believe that shit, they don't believe cops degrade." To illustrate this white racial perspective, he adopted the voice of his generic white persona: "Ah, come on, those beatings? Those people are resisting arrest. I'm tired of this harassment of police officers.” This mimicry implicitly critiques a postracial frame that decontextualizes racial experience and dismisses racial realities with non-racial justifications. Notably, Pryor's articulation of this attitude remains racially indistinct. In other words, Pryor discussed racial profiling with a vagueness that resulted in "a double-voiced address, simultaneously direct and indirect, to the white audience and the implied black audience" (Harris, 2008, p. 27). On one hand, this doubled address allowed him to address white audience members who might otherwise reject a direct racial critique and to acknowledge their oppositional perspective in a manner that avoided the explicit racial dynamics of his truths. Pryor might have alienated his audience at the outset of his bit if he explicitly named the threat of police officers killing black males or labeled police officers as racists. Instead, Pryor invited his audience to remain engaged in his story as he offered a general claim about police interactions and voiced the potential resistance of white audience members. On the other hand, the black audience members and others who would embrace Pryor's critique likely recognize the implied racial sub-text of the postracial frame he employed throughout his narrative. This frame allows whiteness to enjoy the expectation of 
privileged protection and invisibility. However, Pryor's comic reconstruction of white speech patterns foregrounds white identity and marks whiteness so that these privileges and assumptions become visible for at least some of the audience. The ambiguity of the double voiced address allowed Pryor to navigate resistance toward his criticism and gain a broader hearing for his truths while retaining his brutal honesty and ultimately unveiling the destructive and dehumanizing outcomes of dominant racial frames.

Finally, drawing on the presumably familiar experience of receiving a traffic ticket, Pryor exposed disparate racial experiences and social knowledge. "White folks get a ticket, they pull over, 'Hey, Officer. Yes, glad to be of help. Cheerio!' A nigger got to be talkin' 'bout, [loudly, with exaggerated enunciation] 'I am reaching into my pocket for my license!'” In case the reason for narrating his movements is not evident, Pryor sharpened the grave implications: “Cause I don’t wanna be no motherfuckin' accident!” Pryor's punctuating joke stretched the boundaries of the postracial frame, which enables people to euphemistically frame racial profiling and police brutality as inconsequential, excusable "accidents." He confronted the deadly consequences of racial profiling in the criminal justice system and the resulting threat to one's peace of mind. With this final criticism Pryor embodied the "rhetor-as-parrhesiastes," strategically exposing "what particular devil (destructive outcome) hides behind the multiplicity of innocent guises that power may choose to appropriate" (Henderson, 2007, p. 446).

Pryor's critical race humor constructed a parrhesiastic contract that both protected him from retaliation and shielded the audience from a sense of besiegement. This safe space afforded opportunities for risky truth-telling. His tone throughout was playful and light-hearted. His rhythmic pacing and vocal variety created an easy going-demeanor that elicited laughter. The enactment of postracial frames throughout the sketch and his evasion of specific racial referents 
created possibilities for Pryor to gain a broader hearing. With jocularity, he softened and humanized a rage that might have caused some white audience members to disengage. He challenged racial injustice with playfulness instead of acrimony. The point is not that people should be coddled and made to feel at ease about racial oppression, but neither should audiences be confronted in ways that turn them off from a crucial message and cause them to disengage. Likewise, the point is not to suggest that rage and anger should be suppressed, nor to advocate for narrow or restrictive models of criticism. Pryor did not back away from the severity of racism. Rather, his critical race humor offered a strong, yet palatable, outlet for the expression of rage and harsh racial truths. Far from hiding systemic injustices, humor allowed Pryor creative license to introduce harsh racial realities to audiences in ways that they might, in Foucault's (2001) words, "refuse what they previously accepted, or ... accept what they previously refused" (p. 106).

Critical race humor offers a blend of both challenge and support that creates conditions for the audience to embrace truths about racial realities. Pryor carefully attended to the state of mind of his (white) audience members and strategically cultivated common ground before introducing incongruities of racial experiences. These tactics created conditions for Pryor to expose unexamined presuppositions and for the audience to consider non-dominant, racial experiences that it may have otherwise rejected. Significantly, the conclusion to this criticism does not offer direct solutions or actions. Pryor fulfilled the role of an ethical guide, exposing knowledge about racism so as to help his audience enact their own transformation and make their own judgments such that they need not rely on his truth-telling humor. This conclusion further characterizes his critique as personal parrhesia because Pryor "speaks to the other in such a way 
that this other will be able to form an autonomous, independent, full, and satisfying relationship to himself" (Foucault, 2005, p. 379).

\section{Critical Arts and Practices}

Richard Pryor's critical race humor exemplifies the possibilities of humor as both political and personal parrhesia. His narratives defied racism and countered the discursive erasure of material realities of race. Pryor boldly and strategically remembered forgotten histories and gave voice to marginal perspectives that countered the status quo. His brutal truths about race and racism opposed increasingly postracial frames that sought to downplay the continued salience of race. Pryor invited his audience to identify with the emotional, psychological, and material consequences of racism.

To be certain, critical race humor alone will neither eradicate racist patterns of thought nor dismantle institutional racism. However, communication critics have much to gain from understanding critical race humor such as Pryor's as a contemporary practice of parrhesia. A site for parrhesia, such humor represents an important public pedagogical practice that presents opportunities for collaborative association. Scholars and educators might work in concert with artistic truth-tellers in order to expose realities of racial injustice and transform language, meaning, and material relations of power. Scholar-educators will increase the power of our collective aims in partnership with accompanists beyond our disciplinary backyards and academic haunts. Kent Ono (2011) argued, “[A] definition of critical ... should include different approaches, conceptions, and practices" and should recognize "various and diverse critical positions as potential starting points for theorization” (p. 94). Given the challenges of racial truth-telling and criticism in contemporary culture, critical race humor emerges as an unlikely partner for creating spaces for resistance and offering a language of critique that imagines more 
just futures. Giroux (2000) argued that central to any public pedagogy "is the need to begin at those intersections where people actually live their lives and where meaning is produced, assumed, and contested in the unequal relations of power that construct the mundane acts of everyday relations" (p. 355).

Critical race humor represents one such intersection where people regularly turn to make sense of everyday life and struggle over meaning and, therefore, offers an alternative resource through which individuals might learn how to relate to themselves, to others, and to the world around them. In the case of Richard Pryor, his bits on police relations \& the U.S. bicentennial reflect the potential for such humor to engage and redirect the meanings that both shape and are shaped by people's everyday lives. Such humorous problematizations operates pedagogically to reveal ways that meaning, experience, and systemic forces in a particular historical moment establish specific modes of authority and power relationships, sanction particular subject positions, and legitimate certain experiences. In doing so, such humor also has the potential to produce knowledge and skills that might challenge unjust power relationships and systemic forces (Giroux, 2001). In short, critical race humor as a form of public pedagogy and a partner in teaching might provide people with the skills and habits of thought necessary to think critically about racial knowledge and realities.

Courageous artistic truth-tellers provide intellectual and political resources that might inform, inspire, and renew our critical energies, particularly when injustice appears inescapable, insurmountable. Embracing truth-telling artists as partners rather than merely objects of criticism, communication scholars might experience the "joyful commitment" of "working with fellow activists to try to create a culture where our days are full of community, shared projects, and a sense of purpose and hope" (Hartnett, 2010, p. 85). The joy of critical race humor wards 
off haunting specters of cynicism and pessimism. Such artistic criticism affirms my zest for engaged, bold, truth-telling criticism and renews my passion without dulling the urgency for transformation. I hope that other scholars will find similar affirmation, rejuvenation, and inspiration for inventive pedagogy in partnership with critical race humorists who embody the practice of parrhesia. 


\section{References}

Bonilla-Silva, E. (2006). Racism without racists. Color-blind racism and the persistence of racial inequality in the United States, $2^{\text {nd }}$ ed. Lanham, MD: Rowman \& Littlefield.

Boskin, J. (1997). Rebellious laughter: People's humor in American culture. Syracuse, NY: Syracuse University Press.

Browne, S. (1999). Remembering Crispus Attucks: Race, rhetoric, and the politics of commemoration. Quarterly Journal of Speech, 85(2), pp. 169-87. doi:10.1080/00335639909384252

Condit, C. (1990). Rhetorical criticism and audiences. Western Journal of Communication, 54(3), pp. 330-345. doi:10.1080/10570319009374346

Day, A. (2011). Satire and dissent: Interventions in contemporary political debate. Bloomington, IN: Indiana University Press.

Delgado, R. (1989). Storytelling for oppositionists and others: A plea for narrative. Michigan Law Review, 87(8), pp. 2411-2441. doi:10.2307/1289308

Delgado, R., \& Stefancic, J. (2012). Critical race theory: An introduction. $2^{\text {nd }}$ ed. New York, NY: New York University Press.

Dickinson, E. (2012). Addressing environmental racism through storytelling: Toward an environmental justice narrative framework. Communication, Culture, \& Critique, 5, pp. 57-74. doi:10.1111/j.1753-9137.2012.01119.x

Enck-Wanzer, D. (2011). Barack Obama, the Tea Party, and the threat of race: On racial neoliberalism and born again racism. Communication, Culture, \& Critique, 4, pp. 23-30. doi:10.1111/j.1753-9137.2010.01090.x 
Feeney, M. (2005, December 11). Richard Pryor, whose profane, incisive humor revolutionized American comedy, dies at 65. The Boston Globe, B21.

Foucault, M. (2001). J. Pearson (Ed.). Fearless speech. Los Angeles, CA: Semiotext(e).

Foucault, M. (2005). (G. Burchell, trans.). The hermeneutics of the subject: Lectures at the Collège de France 1981-1982. New York, NY: Picador.

Foxx, R. \& Miller, N. (1977). The Redd Foxx encyclopedia of Black humor. Pasadena, CA: Ward Ritchie Press.

Gates, H. L. (1988). The signifying monkey: A theory of African-American literary criticism. New York, NY: Oxford University Press.

Gelvin, M. (2000). Truth and the comedic art. Albany, NY: State University of New York Press.

Giroux, H. (2000). Public pedagogy as cultural politics: Stuart Hall and the 'crisis' of culture. Cultural Studies, 14(2), pp. 341-360. doi:10.1080/095023800334913

Giroux, H. (2001). Public spaces, private lives: Beyond the culture of cynicism. Lanham, MD: Rowman \& Littlefield.

Goltz, D. B. (2013). The critical-norm: The performativity of critique and the potentials of performance. Text and Performance Quarterly, 33(1), pp. 22-41. doi:10.1080/10462937.2012.733887

Haggins, B. (2007). Laughing mad: The Black comic persona in post-soul America. New Brunswick, NJ: Rutgers University Press.

Hall, S. (1996). Introduction: Who needs identity? In S. Hall and P. du Gay (eds.), Questions of cultural identity (pp. 1-17). Thousand Oaks, CA: Sage. 
Harris, K. M. (2008). ‘That nigger's crazy’: Richard Pryor, racial performativity, cultural critique. In A. T. McCluskey, (ed.), Richard Pryor: The Life and Legacy of a 'Crazy' Black Man (pp. 23-38). Bloomington: Indiana University Press.

Hartnett, S. J. (2010). Communication, social justice, and joyful commitment. Western Journal of Communication, 74(1), pp. 68-93. doi:10.1080/10570310903463778

Hasian, Jr., M., \& Delgado, F. (1998). The trials and tribulations of racialized critical rhetorical theory: Understanding the rhetorical ambiguities of Proposition 187. Communication Theory, 8(3), pp. 245-270. doi:10.1111/j.1468-2885.1998.tb00221.x

Henderson, G. L. (2007). The "parrhesiastic game": Textual self-justification in spiritual narratives of early modern women. Rhetoric Society Quarterly, 37(4), pp. 423-451. doi:10.1080/02773940601078072

Hoerl, K. (2012). Selective amnesia and racial transcendence in news coverage of President Obama's inauguration. Quarterly Journal of Speech, 98(2), pp. 178-202. doi:10.1080/00335630.2012.663499

Jarratt, S. C. (2010). The prospects for the public work of rhetoric: A coda on codes. In J. Ackerman \& D. Coogan (Eds.), The public work of rhetoric: Citizen-scholars and civic engagement (pp. 283-296). Columbia, SC: University of South Carolina Press.

Jenkins, R. S. (1994). Subversive laughter: The liberating power of comedy. New York, NY: Free Press.

Jones, B., \& Mukherjee, R. (2010). From California to Michigan: Race, rationality, and neoliberal governmentality. Communication and Critical/Cultural Studies, 7(4), pp. 401422. doi:10.1080/14791420.2010.523431 
Jones, J. P. (2009). Entertaining politics: Satiric television and political engagement. Lanham, MD: Rowman \& Littlefield.

Kendall, F. E. (2006). Understanding White privilege: Creating pathways to authentic relationships across race. New York, NY: Routledge.

Kercher, S. (2006). Revel with a cause: Liberal satire in postwar America. Chicago, IL: University of Chicago Press.

Lacy, M. \& Ono, K. A. (Eds.). (2011). Critical rhetorics of race. New York, NY: New York University Press.

Ladson-Billings, G., \& Tate, W. F. (1995). Toward a critical race theory of education. Teachers College Record, 97(1), pp. 47-68.

Lawrence, C. R. (1990). If he hollers let him go: Regulating racist speech on campus. Duke Law Journal, 1990(3), pp. 431-483. doi:10.2307/1372554

Lerner, R. (2009). Playing the fool: Subversive laughter in troubled times. Chicago, IL: University of Chicago Press.

López, I. H. (2006). White by law: The legal construction of race. New York, NY: New York University Press.

Lucaites, J. L. (1997). The irony of 'equality' in Black abolitionist discourse: The case of Frederick Douglass's 'What to the slave is the Fourth of July?” In T. W. Benson (Ed.), Rhetoric and political culture in nineteenth-century America (pp. 47-69), East Lansing, MI: Michigan State University Press.

Markovits, E. (2008). The politics of sincerity: Plato, frank speech, and democratic judgment. University Park, PA: Pennsylvania State University Press. 
Matsuda, M. J. (1987). Looking to the bottom: Critical legal studies and reparations. Harvard Civil Rights-Civil Liberties Law Review, 22, pp. 323-399.

Monoson, S. S. (2000). Plato's democratic entanglements: Athenian politics and the practice of philosophy. Princeton, NY: Princeton University Press.

Ober, J. (1989). Mass and elite in democratic Athens. Princeton, NJ: Princeton University Press.

Ober, J. (1994). How to criticize democracy in late fifth- and fourth-century Athens. In J. P. Euben, J. R. Wallach, \& J. Ober (Eds.), Athenian political thought and the reconstruction of American democracy (pp. 149-171). Ithaca, NY: Cornell University Press.

Olmsted, A. P. (1998). Words are acts: Critical Race Theory as a rhetorical construct. Howard Journal of Communication, 9, 323-331. doi:10.1080/106461798246934

Ono, K. A. (2011). Critical: A finer edge. Communication and Critical/Cultural Studies, 8(1), pp. 93-96. doi:10.1080/14791420.2011.543332

Pryor, R. (1974). That nigger's crazy. New York, NY: Reprise Records.

Pryor, R. (1976). Bicentennial nigger. Burbank, CA: Warner Bros. Records.

Pryor, R. (1985/1971). Live and Smokin'. Stamford, CT: Vestron Video.

Pryor, R., \& Gold, T. (1995). Pryor convictions, and other life sentences. New York, NY: Pantheon.

Rossing, J. P. (2010). Critical intersections and comic possibilities: Extending racialized critical rhetorical scholarship. Communication Law Review, 10(1), pp. 10-27.

Rossing, J. P. (2012). Deconstructing postracialism: Humor as a critical, cultural project. Journal of Communication Inquiry, 36(1), pp. 44-61. doi:10.1177/0196859911430753

Saxonhouse, A. W. (2006). Free speech and democracy in ancient Athens. New York, NY: Cambridge University Press. 
Squires, C., Watts, E. K., Vavrus, M. D., Ono, K. A., Feyh, K., Callafell, B. M., \& Brouwer, D. C. (2010). What is this "post-" in postracial, postfeminist... (Fill in the blank)?" Journal of Communication Inquiry, 34(3), pp. 210-253. doi:10.1177/0196859910371375

Stanford, G. (2005, December 13). Richard Pryor: No joke, he gave us the truth. Milwaukee Journal Sentinel, p. 10.

Terrill, R. E. (2003). Irony, silence, and time: Frederick Douglass on the fifth of July. Quarterly Journal of Speech, 89(3), pp. 216-234. doi:10.1080/0033563032000125322

Test, G. A. (1991). Satire: Spirit and art. Tampa, FL: University of South Florida Press.

Waisanen, D. J. (2009). A citizen's guide to democracy inaction: Jon Stewart and Stephen Colbert's comic rhetorical criticism. Southern Communication Journal, 74(2), pp. 118140. doi:10.1080/10417940802428212

Waldron, C. (2006, January 9). Richard Pryor comedy legend 1940-2005. Jet, p. 6.

Walzer, A. E. (2013). Parresia, Foucault, and the classical rhetorical tradition. Rhetoric Society Quarterly, 43.1, pp. 1-21. doi: 10.1080/02773945.2012.740130

Watkins, M. (1994). On the real side: Laughing, lying, and signifying: The underground tradition of African-American humor that transformed American culture, from slavery to Richard Pryor. New York, NY: Simon \& Schuster.

Watkins, M. (2005, December 12). Richard Pryor, who turned humor of the streets into social satire, dies at 65. New York Times, A24.

West, C. (2004). Democracy matters: Winning the fight against imperialism. New York, NY: Penguin.

Williams, P. J. (1987). Spirit-murdering the messenger: The discourse of finger pointing as the law's response to racism. University of Miami Law Review, 42, pp. 127-157. 
Zolten, J. J. (1993). Black comedians: Forging an ethnic image. Journal of American Culture, 16(2), pp. 65-76. doi:10.1111/j.1542-734X.1993.00065.x 